\title{
Local Communities Demand for Food Tree Species and the Potentialities of Their Landscapes in Two Ecological Zones of Burkina Faso
}

\author{
Daniabla Natacha Edwige Thiombiano ${ }^{1 *}$, Niéyidouba Lamien ${ }^{2}$, \\ Ana M. Castro-Euler ${ }^{3}$, Barbara Vinceti ${ }^{4}$, Dolores Agundez ${ }^{5}$, Issaka Joseph Boussim ${ }^{1}$ \\ ${ }^{1}$ Laboratoire de Biologie et d'Ecologie Végétales, Université de Ouagadougou, Ouagadougou, Burkina Faso \\ ${ }^{2}$ Département de Production Forestière, Institut de l'Environnement et de Recherches Agricoles, Koudougou, \\ Burkina Faso \\ ${ }^{3}$ Instituto Estadual de Floresta, Embrapa Amapa Rodovia Juscelino Kubitschek, Macapa, Brazil \\ ${ }^{4}$ Bioversity International, CGIAR, Headquaters: Via Dei TreDenari, Rome, Italy \\ ${ }^{5}$ INIA-CIFOR, Dpto Sistemas y Recursos Forestales, Carretera de la Coruña, Madrid, Spain \\ Email: "thionat@yahoo.fr
}

Received March 19 $9^{\text {th }}, 2013$; revised May $23^{\text {rd }}, 2013$; accepted June $9^{\text {th }}, 2013$

Copyright (C) 2013 Daniabla Natacha Edwige Thiombiano et al. This is an open access article distributed under the Creative Commons Attribution License, which permits unrestricted use, distribution, and reproduction in any medium, provided the original work is properly cited.

\begin{abstract}
We examined demand and supply of Food Tree Species (FTS) products in Burkina Faso. The hypotheses were: 1) demand for FTS products by local communities exceeds what can be sustainably extracted, and 2) local communities of the Sudanian zone have access to more diverse FTS products compared to Sahelian zone. Surveys were conducted in 300 households and 360 quadrats in landscapes surrounding 6 villages to determine the diversity, richness and availability of FTS. The results indicate that local communities tend to exploit FTS which are rare to find or absent in the landscape surrounding their village. While the range of FTS largely exploited tends to coincide across the two ecological zones, the diversity and density of the preferred FTS are discordant between the two zones. The results of the present study further support the need for conservation and restoration strategies to sustain the local communities demand for FTS products.
\end{abstract}

Keywords: Human Feeding; Food Security; Indigenous Knowledge; Quantitative Ethnobotany; Diversity, Threats

\section{Introduction}

Globally, 1.6 billion people strongly rely on forest resources for their livelihoods (Pimental et al., 1997). In most developing countries, forested landscapes play an important role for poor individuals and households (Langat \& Cheboiwo, 2010). In sub-Saharan Africa, dry forest and woodlands surrounding rural settlements supply a vast array of wild natural resources (i.e., firewood, food, construction materials, medicine and fibers) for home consumption and sale (Shackleton \& Gumbo, 2010).

In Burkina Faso, the basic diet in rural areas is not very diverse. The thick porridge processed from millet, sorghum or maize flour, locally referred to as "Tô", associated with sauce containing vegetables and condiments, constitutes the staple food. It is daily cooked five times per week and represents $83 \%$ of household meals (Soulama, 1990). Apart from the sauce, which can contain a variety of ingredients, starch is the main nutrient found in the porridge. With such dietary habits, what contributes to alleviating nutritional deficiencies in the diet of this country? Many studies have shown the pivotal role that Food Tree Species (FTS) play in balancing diets as additional ingredients and snacks, serving as staple foods during food

${ }^{*}$ Corresponding author. shortage periods, and generating income that enables to buy additional food products not available locally. Mertz et al. (2001) and Kristensen \& Lykke (2003) in their studies in the south eastern and the south central parts of Burkina Faso respectively, have reported that about 17 trees species are used by local communities as ingredients for sauces or condiments. Products from a total of 21 fruit tree species were found to be consumed as snacks by children (Lamien et al., 2009). According to Shackleton et al. (2011) and Thiombiano et al. (2012), forests and woodlands supply rural dwellers with a wide range of foods, and contribute to food security and nutrition directly and indirectly by providing fruits, seeds and leaves. Most frequently, women are responsible for gathering, processing and selling non-timber forest products, generating income or using the products for home consumption; these activities indicate the key role played by women in food security strategies (Hasalkar \& Jadhav, 2004; Shackleton et al., 2011).

Unfortunately, a sustainable provision of products and services by forest ecosystems is being threatened by their increasing degradation and accelerated conversion of forest land to alternative land uses (Langat \& Cheboiwo, 2010). FAO (2001) statistics indicate that tropical regions lost 15.2 million hectares of forests per year during the 1990s. In Burkina Faso, Ouéd- 
raogo et al. (2010) found that conversion of forest land to cropland proceeded at an annual rate of $0.96 \%$, while human population density shifted from 17 to 30 inhabitants $/ \mathrm{km}^{2}$ in the 20 years between 1986 and 2006. Among the drivers of land use change, Paré (2008) identified demographic and economic factors as key ones, and detected a close correlation between biodiversity status or change in African ecosystems and the spatio-temporal variation in human population density, following the common pattern of a positive relationship between an increasing population density and magnitude of the threats to biodiversity.

Ethnobotanical research, in combination with quantitative ecological sampling methods, based on the use of plots or transects, has gained considerable importance over last decades (Cotton, 1996; Thomas et al., 2009). Despite the many ethnobotanical studies carried out in Burkina Faso (Mertz et al., 2001; Kristensen \& Lykke, 2003; Belem et al., 2008; Lamien et al., 2009), up to now, little work has been undertaken using quantitative ethnobotany approaches, which enable to assess the sustainability in exploitation of non-timber forest products by local communities, and whether demand for these products goes beyond the potential supply. Knowledge of these elements is of paramount importance to gear policy-making towards a more sustainable use of the diversity of woody species, in a context of expanding cultivated lands due to a rapid population growth and of increasingly unpredictable precipitation patterns. The aim of the present study is to establish evidence that local communities demand for FTS products is exceeding the poten- tial of their surrounding landscapes, thereby stimulating conservation and restoration actions. We formulated the following hypotheses: 1) the demand for FTS products by local communities exceeds what can be sustainable extracted within the surrounding landscape in both ecological zones, and 2) due to the more favorable environmental conditions (i.e., higher rainfall), the local communities of the Sudanian zone have access to a more diverse and richer range of FTS compared to those within the Sahelian zone in Burkina Faso. Therefore, surveys were conducted at households and landscape levels, to determine what FTS products are frequently used by households to meet their food and income needs, and to understand what is their availability in the surrounding landscapes.

\section{Material and Methods}

\section{Study Area}

The study was conducted at 6 sites located in the Sahelian and Sudanian ecological zones of Burkina Faso as they are described by Fontes and Guinko (1995). In each ecological zone (Figure 1), 3 villages in the Sudanian zone (namely Barcé, Péni and Sara) and 3 in the Sahelian zone (Barsalgho, Bourgou, \& Pobé-Mengao) were randomly selected for the study from Burkina Faso's INSD (2010) most recent census database. The characteristics of the selected villages are summarized in Table 1

The sites in the Sahelian zone, the vegetation before human

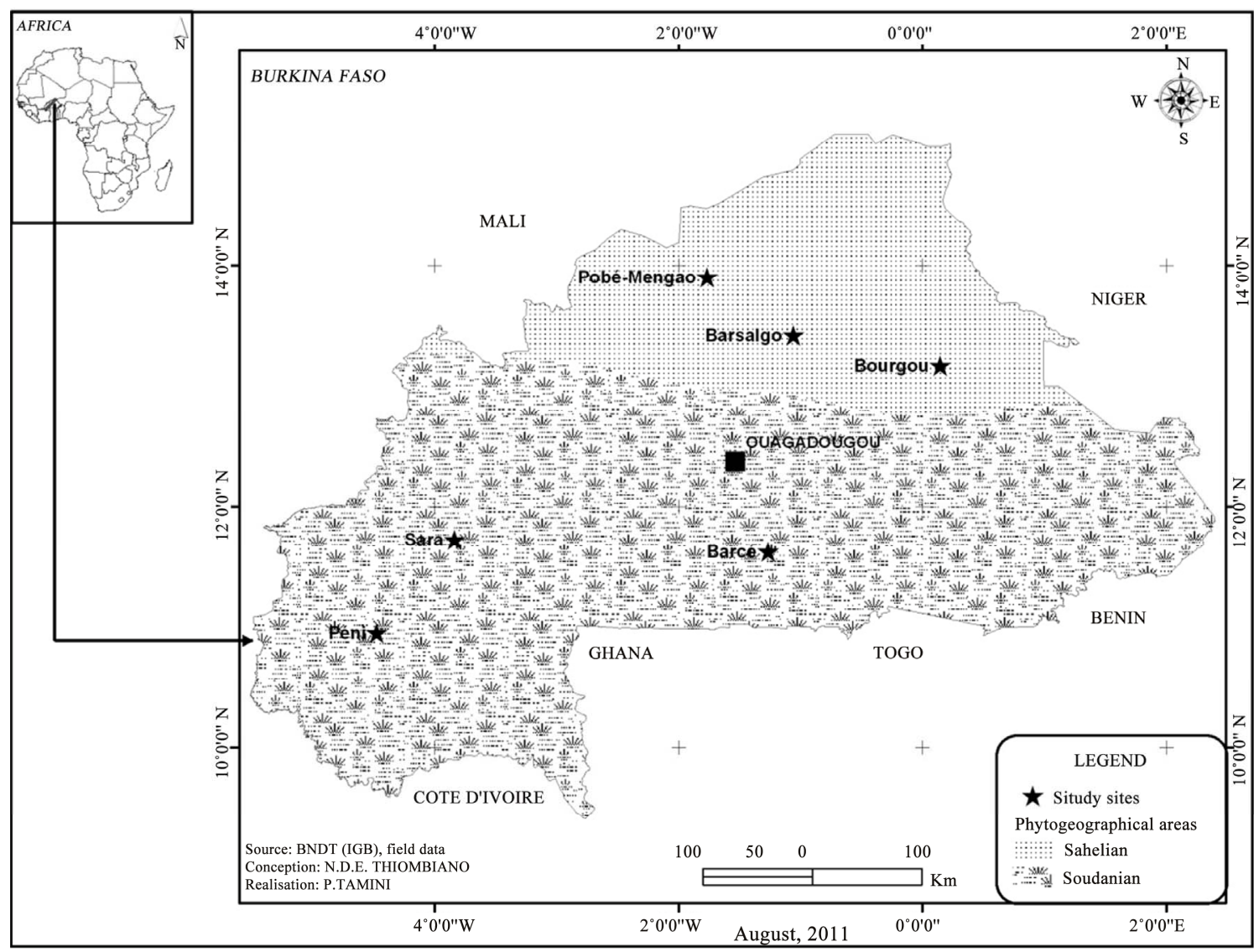

Figure 1.

Location of the different study sites in Burkina Faso. 
Table 1.

Characteristics of the study sites.

\begin{tabular}{|c|c|c|c|c|c|c|}
\hline Ecological zones & Villages & No households & $\begin{array}{c}\% \text { households } \\
\text { surveyed }\end{array}$ & $\begin{array}{c}\text { Population } \\
\text { densities }\left(\operatorname{Inh} \cdot \mathrm{km}^{-2}\right)\end{array}$ & Coordinates & $\begin{array}{c}\text { Annual } \\
\text { rainfall }(\mathrm{mm})\end{array}$ \\
\hline \multirow{3}{*}{ Sahelian } & Barsalgho & 1571 & 3 & 64 & $13^{\circ} 25^{\prime} \mathrm{N}, 01^{\circ} 04^{\prime} \mathrm{W}$ & \multirow{3}{*}{$400-600$} \\
\hline & Bourgou & 353 & 14 & 48 & $13^{\circ} 09^{\prime} \mathrm{N}, 00^{\circ} 09^{\prime} \mathrm{W}$ & \\
\hline & Pobé-Mengao & 578 & 9 & 28 & $13^{\circ} 53^{\prime} \mathrm{N}, 01^{\circ} 46^{\prime} \mathrm{W}$ & \\
\hline \multirow{3}{*}{ Sudanian } & Barcé & 124 & 40 & 68 & $11^{\circ} 36^{\prime} \mathrm{N}, 01^{\circ} 16^{\prime} \mathrm{W}$ & \multirow{3}{*}{$700-1000$} \\
\hline & Péni & 659 & 8 & 82 & $10^{\circ} 56^{\prime} \mathrm{N}, 04^{\circ} 29^{\prime} \mathrm{W}$ & \\
\hline & Sara & 608 & 8 & 40 & $10^{\circ} 57^{\prime} \mathrm{N}, 04^{\circ} 25^{\prime} \mathrm{W}$ & \\
\hline
\end{tabular}

impact was semi-desert grasslands and thorny shrub lands to wooded grasslands and bush land. The traditional parkland systems (integrated crop-tree-livestock systems), are the main source of food, income and environmental services, but are rapidly deteriorating; biodiversity and cover of woody species is being lost, soil fertility is declining from already low levels due to exhaustive cropping practices and soil erosion (Bationo et al., 2003).

The sites in the Sudanian zone, the original vegetation is woodland and dry forest. At present, the main land uses type are: fallow, agro-forestry parklands with food crops, pockets of gallery forests without cultivation, some sacred hills. Clearcutting systems are used in areas under both short and long term fallow.

\section{Ethnobotanical Survey}

In each ecological zone, 50 households per village were randomly selected using the village households list from the most recent population census database (INSD, 2010). A total of 300 informants from the selected 300 households were interviewed. The informants were all female as it is known in the region that women have a more significant role in the collection, trade and processing of the majority of non-timber forest products (Gausset et al., 2005). Using a semi-structured questionnaire, informants were asked to list down all the tree species which are sources of edible products, directly consumed as staple foods, snacks, vegetables or as supplements to diets during food shortage periods. Respondents were interviewed in isolation to avoid influencing each other's answers. Each interview was carried out in the informant's local language, in order to facilitate understanding of the questions and to obtain precise information on local dietary habits.

\section{Ecological Sampling}

The FTS inventory was carried out in the landscapes surrounding the 6 villages listed in Table 1 . With regard to sampling design, among the various methods for abundance estimation described in Krebs (1999), line transect, based on individual quadrats as sampling units, was adopted, as recommended by Mahamane and Saadou (2008) for the type of vegetation found in the study sites. Four transects of $5 \mathrm{~km}$ each were established north, south, west and east from each village, in order to cover the FTS products harvesting areas around each village. The results of surveys showed that women, who generally cover long distances to harvest FTS products in the areas surrounding the village, cannot go beyond $5 \mathrm{~km}$ from their houses.
Along each transect, a total of 15 quadrats of $50 \times 50 \mathrm{~m}^{2}$ and 20 $\times 20 \mathrm{~m}^{2}$ were defined respectively for the inventory of adult trees and seedlings (Mahamane \& Saadou, 2008). A total of 360 quadrats were established in both Sahelian and Sudanian zones. The distance considered between two quadrats was 333 $\mathrm{m}$ to cover the $5 \mathrm{~km}$ radius. The smaller quadrats to record seedlings were sub-plots established within the larger quadrats of $50 \times 50 \mathrm{~m}^{2}$. FTS stems with girth $\geq 10 \mathrm{~cm}$ at $20 \mathrm{~cm}$ from the soil were considered as adult trees while stems with girth $<10$ $\mathrm{cm}$ were considered as seedlings (Zida, 2007). The list of FTS to be inventoried was determined by the preferences expressed in the households' survey, in the same village. The number of stems of adult trees and seedlings was recorded.

\section{Data Analysis}

To establish the list of FTS and their relative importance in the households, the frequency of use per species was estimated by taking into account the proportion of times a plant was mentioned out of the total number of interviews. This technique reveals the relative importance of each cited species. The adult stems and seedlings densities of each species was estimated by extrapolating the number of individuals found in the $50 \times 50 \mathrm{~m}^{2}$ and $20 \times 20 \mathrm{~m}^{2}$ quadrats to a hectare. Descriptive statistics were computed from these derived variables. To compare adult trees and seedlings densities within and between ecological zones, the dataset was submitted to normality test. The Kolmogrov-Smirnov statistic was significant, indicating a violation of the assumption of normality. The comparison was therefore, performed using the Mann-Whitney U test, alternative to the independent-samples t-test (Pallant, 2010).

Among the various indices of diversity found in the literature, the reciprocal of Simpson's $(D)$ index was used to estimate the FTS richness, as it provide a good estimate of diversity for a relatively small sample size (Magurran, 2004). The index was derived from households surveys and landscape-scale FTS inventories. We assumed the household similar to the quadrat in terms of number of species cited or found in the different units. The Richness Shared Index (RSI) suggested by Ladio and Lozada (2004) was adopted to analyze the richness cited per informant or found per quadrat with respect to the total richness mentioned by the total number of people interviewed or found in the total number of quadrats. An independent sample t-test was used to compare the Simpson reciprocal diversity index $(1 / D)$ and the Richness Share Index $(R S I)$ between ecological zones and between households' survey and landscapes FTS data, which were normally distributed. The guidelines for Cohen (1988) partial eta squared statistic $\left(\eta_{p}{ }^{2}\right)$, reported in Pal- 
lant (2010), were used for effect size interpretation.

In order to determine how the species used in the households or found in the quadrats are similar among the different plant communities, we computed the Jaccard (JSI) and Morisita-Horn $\left(C_{M H}\right)$ similarity indices (Magurran, 2004). The different secondary variables were calculated using the Microsoft Office Excel 2007 and all the statistical analyses were performed with IBM SPSS Statistic 19.

\section{Results}

\section{Importance of FTS in Households and Landscapes}

The proportion of households which have indicated a particular species as source of food, and the proportion of quadrats where this species was found, according to the ecological zone, are presented in Table 2. A total of 30 FTS from 16 families were recorded in the household surveys and quadrat inventories. The inventory data showed that 13 species were common to the two ecological zones, 5 were specific to the Sahelian zone and 12 were specific to the Sudanian zone. The households survey resulted in 10 common species, 5 restricted to the Sahelian and 10 to the Sudanian zone.

In both ecological zones, species such as Adansonia digitata, Lannea microcarpa, Parkia biglobosa and Vitellaria paradoxa were mentioned by more than $70 \%$ of the respondents as sources of food, but were seldom found in the quadrats of the landscapes surrounding the villages, with the exception of Vitellaria paradoxa and Parkia biglobosa which were respec-

Table 2.

Proportions $(\%)$ of households $(n=300)$ and quadrats $(n=360)$ where FTS were recorded in the two ecological zones of Burkina Faso.

\begin{tabular}{|c|c|c|c|c|}
\hline \multirow{2}{*}{ Species } & \multicolumn{2}{|c|}{ Sahelian zone } & \multicolumn{2}{|c|}{ Sudanian zone } \\
\hline & Households & Quadrats & Households & Quadrats \\
\hline Adansonia digitata & 98 & 8 & 95 & 2 \\
\hline Afzelia africana & 0 & 0 & 14 & 3 \\
\hline Annona senegalensis & 0 & 0 & 5 & 15 \\
\hline Balanites aegyptiaca & 1 & 66 & 1 & 7 \\
\hline Bombax costatum & 74 & 1 & 28 & 10 \\
\hline Boscia senegalensis & 6 & 9 & 0 & 0 \\
\hline Cadaba farinosa & 3 & 4 & 0 & 0 \\
\hline Capparis corymbosa & 0 & 0 & 2 & 1 \\
\hline Ceiba pentandra & 0 & 0 & 5 & 0 \\
\hline Detarium microcarpum & 1 & 0 & 11 & 13 \\
\hline Diospyros mespiliformis & 4 & 4 & 0 & 16 \\
\hline Ficus sycomorus & 0 & 1 & 1 & 1 \\
\hline Gardenia erubescens & 0 & 0 & 13 & 2 \\
\hline Grewia bicolor & 0 & 3 & 0 & 4 \\
\hline Landolphia heudelotii & 0 & 0 & 10 & 1 \\
\hline Lannea acida & 0 & 0 & 0 & 23 \\
\hline Lannea microcarpa & 91 & 4 & 86 & 15 \\
\hline Leptadenia hastata & 57 & 0 & 5 & 0 \\
\hline Maerua crassifolia & 5 & 4 & 0 & 0 \\
\hline Parkia biglobosa & 81 & 0 & 97 & 32 \\
\hline Piliostigma reticulatum & 0 & 35 & 0 & 6 \\
\hline Saba senegalensis & 39 & 1 & 73 & 1 \\
\hline Sclerocarya birrea & 0 & 13 & 16 & 6 \\
\hline Securidaca longepedunculata & 0 & 0 & 0 & 8 \\
\hline Strychnos spinosa & 0 & 0 & 11 & 11 \\
\hline Tamarindus indica & 1 & 7 & 0 & 2 \\
\hline Vitellaria paradoxa & 71 & 3 & 97 & 77 \\
\hline Vitex doniana & 1 & 0 & 17 & 6 \\
\hline Ximenia americana & 0 & 2 & 19 & 5 \\
\hline Ziziphus mauritiana & 0 & 12 & 0 & 0 \\
\hline
\end{tabular}


tively encountered in $77 \%$ and $32 \%$ of the quadrats in the Sudanian zone. Some species such as Afzelia africana, Gardenia erubescens, Landolphia heudelotii, Vitex doniana and Ximenia americana were restricted to the Sudanian zone. On the opposite, very few informants from the Sahelian zone mentioned Balanites aegyptica and Piliostigma reticulatum as sources of food although they were encountered in $66 \%$ and $35 \%$ of the quadrats respectively. In the Sudanian zone, important species with similar use and presence patterns were Lannea acida (cf. $23 \%$ and $0 \%$ from household surveys and quadrat inventories, respectively) and Diospyros mespiliformis (cf. 16\% and $0 \%$ from household surveys and quadrat inventories, respectively). Piliostigma reticulatum and Securidaca longepedunculata were not recorded in household surveys as sources of food but these two species were considered in the quadrat inventories because it is well known from other sources that these species are used as food ingredients. Leptadenia hastata, a liana, was reported by half of the households in the Sahelian zone and few households in the Sudanian zone but the FTS inventory did not include it.

\section{Landscapes' Potentialities of Food Tree Species}

The potentialities of FTS in the landscapes are expressed in terms of list of the species that occur in the area, and the density of their adult trees and seedlings in the two ecological zones (Table 3). A Mann-Whitney U test revealed greater seedlings densities than adult trees, both in the Sahelian zone (seedlings

Table 3.

Adult trees and seedlings of FTS densities (Stems/ha $\pm \mathrm{sd}$ ) in the two ecological zones of Burkina Faso.

\begin{tabular}{|c|c|c|c|c|}
\hline \multirow{2}{*}{ Species } & \multicolumn{2}{|c|}{ Sahelian zone } & \multicolumn{2}{|c|}{ Sudanian zone } \\
\hline & Adult trees & Seedlings & Adult trees & Seedlings \\
\hline Acacia macrostachya & $0 \pm 0$ & $9 \pm 6$ & $0 \pm 0$ & $15 \pm 10$ \\
\hline Adansonia digitata & $5 \pm 3$ & $4 \pm 0$ & $8 \pm 7$ & $4 \pm 0$ \\
\hline Afzelia africana & $0 \pm 0$ & $0 \pm 0$ & $7 \pm 6$ & $32 \pm 17$ \\
\hline Annona senegalensis & $0 \pm 0$ & $0 \pm 0$ & $13 \pm 11$ & $76 \pm 72$ \\
\hline Balanites aegyptiaca & $15 \pm 12$ & $54 \pm 65$ & $10 \pm 6$ & $19 \pm 16$ \\
\hline Bombax costatum & $8 \pm 6$ & $8 \pm 0$ & $5 \pm 2$ & $14 \pm 10$ \\
\hline Boscia senegalensis & $11 \pm 10$ & $36 \pm 31$ & $0 \pm 0$ & $0 \pm 0$ \\
\hline Cadaba farinosa & $5 \pm 2$ & $11 \pm 11$ & $0 \pm 0$ & $0 \pm 0$ \\
\hline Capparis corymbosa & $0 \pm 0$ & $9 \pm 4$ & $4 \pm 0$ & $4 \pm 0$ \\
\hline Detarium microcarpum & $0 \pm 0$ & $0 \pm 0$ & $24 \pm 28$ & $83 \pm 100$ \\
\hline Diospyros mespiliformis & $10 \pm 6$ & $11 \pm 8$ & $7 \pm 5$ & $32 \pm 35$ \\
\hline Ficus ingens & $0 \pm 0$ & $0 \pm 0$ & $0 \pm 0$ & $9 \pm 2$ \\
\hline Ficus sycomorus & $4 \pm 0$ & $0 \pm 0$ & $10 \pm 8$ & $4 \pm 0$ \\
\hline Gardenia erubescens & $0 \pm 0$ & $0 \pm 0$ & $9 \pm 5$ & $35 \pm 12$ \\
\hline Grewia bicolor & $5 \pm 2$ & $8 \pm 0$ & $4 \pm 0$ & $13 \pm 6$ \\
\hline Landolphia heudelotii & $0 \pm 0$ & $0 \pm 0$ & $4 \pm 0$ & $11 \pm 9$ \\
\hline Lannea acida & $0 \pm 0$ & $0 \pm 0$ & $8 \pm 6$ & $23 \pm 14$ \\
\hline Lannea microcarpa & $5 \pm 2$ & $4 \pm 0$ & $10 \pm 7$ & $13 \pm 12$ \\
\hline Maerua angolensis & $0 \pm 0$ & $5 \pm 2$ & $0 \pm 0$ & $4 \pm 0$ \\
\hline Maerua crassifolia & $5 \pm 2$ & $15 \pm 13$ & $0 \pm 0$ & $0 \pm 0$ \\
\hline Parkia biglobosa & $0 \pm 0$ & $0 \pm 0$ & $10 \pm 8$ & $17 \pm 17$ \\
\hline Piliostigma reticulatum & $10 \pm 10$ & $66 \pm 96$ & $9 \pm 7$ & $21 \pm 26$ \\
\hline Saba senegalensis & $4 \pm 0$ & $0 \pm 0$ & $6 \pm 3$ & $6 \pm 4$ \\
\hline Sclerocarya birrea & $6 \pm 3$ & $9 \pm 6$ & $9 \pm 7$ & $17 \pm 18$ \\
\hline Securidaca longepedunculata & $0 \pm 0$ & $0 \pm 0$ & $8 \pm 6$ & $62 \pm 119$ \\
\hline Strychnos spinosa & $0 \pm 0$ & $0 \pm 0$ & $9 \pm 9$ & $69 \pm 58$ \\
\hline Tamarindus indica & $6 \pm 5$ & $8 \pm 0$ & $5 \pm 2$ & $10 \pm 8$ \\
\hline Vitellaria paradoxa & $4 \pm 0$ & $0 \pm 0$ & $25 \pm 23$ & $110 \pm 163$ \\
\hline Vitex doniana & $0 \pm 0$ & $0 \pm 0$ & $4 \pm 1$ & $15 \pm 12$ \\
\hline Ximenia americana & $4 \pm 0$ & $9 \pm 2$ & $5 \pm 2$ & $21 \pm 19$ \\
\hline Ziziphus mauritiana & $7 \pm 5$ & $18 \pm 17$ & $0 \pm 0$ & $8 \pm 6$ \\
\hline
\end{tabular}


$M d=16, N=373$ and adult trees $M d=8, N=322 ; U=31322$, $z=-11.08, p=0.000, r=0.42)$ and the Sudanian zone (seedlings $M d=24, N=603$ and adult trees $M d=8, N=481 ; U=$ $72,503, z=-14.31, p=0.000, r=0.43)$. The eta squared values $\left(\eta_{p}{ }^{2}=0.42\right.$ in Sahelian zone and 0.43 in Sudanian zone) indicate a large size effect within ecological zones.

Comparison between ecological zones revealed greater densities in the Sudanian than the Sahelian zone both for seedlings (Sudanian zone $M d=24, N=603$ and Sahelian zone $M d=16, N=373 ; U=94,737, z=-4.16, p=0.000, r=0.13$ ) and adult trees (Sudanian zone $M d=8, N=481$ and Sahelian zone $M d=8, N=322 ; U=69,024, z=-2.74, p=0.006, r=$ $0.10)$. The eta squared values $\left(\eta_{p}{ }^{2}=0.13\right.$ for seedlings and 0.10 for adult trees) also indicates a large effect between ecological zones.

Richness and diversity of FTS in households and landscapes.

The species richness and diversity were measured through the reciprocal of Simpson diversity index $(1 / D)$, the mean species richness per households and quadrat, and the Richness Share Index $(R S I)$. These are presented in Table 4.

To determine the difference between Sahelian and Sudanian zones in the $1 / D$ estimated from households' surveys and landscape FTS inventories, an independent-samples t-test was conducted. There was no significant difference in $1 / D$ both for households (Sahelian $M=6.726$, sd $=0.952$ and Sudanian $M=$ 6.145 , sd $=0.576 ; t(4)=0.905, p=0.43$ two-tailed) and landscapes (Sahelian $M=3.283$, sd $=1.265$ and Sudanian $M=$ $3.330, \mathrm{sd}=0.276 ; t(4)=-0.063, p=0.95$ two-tailed). The magnitude of the $1 / D$ differences (means difference $=0.58$, $95 \% C I=-1.202$ to 2.365$)$ was larger $\left(\eta_{p}{ }^{2}=0.16\right)$ for households survey data than for landscapes inventory data (means difference $=-0.047,95 \% C I=-2.123$ to $2.029 ; \eta_{p}{ }^{2}=0.0009$ ).

An independent-samples t-test was also conducted to compare the reciprocal of Simpson indices $(1 / D)$ between households' survey and landscape FTS inventory data sets within each of the two ecological zones. There was a significant difference in $1 / D$ both for the Sahelian zone (Households $M=$ 6.726, $\mathrm{sd}=0.952$ and Landscapes $M=3.283$, sd $=1.265 ; t(4)=$ 3.766, $p=0.020$ two-tailed) and the Sudanian zone (Households $M=6.145$, sd $=0.576$ and Landscapes $M=3.330$, sd = $0.276 ; t(4)=7.627, p=0.002$ two-tailed). The magnitude of the $1 / D$ differences (households means difference $=3.44,95 \% C I=$ 0.905 to $5.981 ; \eta_{p}{ }^{2}=0.78$-landscapes means difference $=2.81$, $95 \% C I=1.790$ to $3.839 ; \eta_{p}{ }^{2}=0.93$ ) was considerable both for
Sahelian and Sudanian zones.

To compare the Richness Share Indices (RSI) between households' survey and landscape FTS inventory data sets in the Sahelian and Sudanian ecological zones, an independentsamples t-test was performed. There were significant differences in $R S I$ both for Sahelian (Households $M=0.511$, sd = 0.049 and Landscapes $M=0.019 \mathrm{sd}=0.00 ; t(2)=17.494, p=$ 0.003 two-tailed) and Sudanian (Households $M=0.470, \mathrm{sd}=$ 0.045 and Landscapes $M=0.018$, sd $=0.000 ; t(2)=17.53, p=$ 0.003 two-tailed). The magnitude of the RSI differences (households means difference $=0.491,95 \% C I=0.028$ to $0.370 ; \eta_{p}{ }^{2}=0.99$ ) and landscapes means difference $=0.452$, $95 \% C I=0.341$ to $0.563 ; \eta_{p}^{2}=0.99$ ) were large for both ecological zones.

To compare the Richness Share Indices estimated from households' survey and landscape FTS inventory between Sahelian and Sudanian ecological zones, an independent-samples t-test was conducted. There was no significant difference in $R S I$ for households data set (Sahelian $M=0.511$, sd $=0.049$ and Sudanian $M=0.470$, sd $=0.045 ; t(4)=1.065 p=0.35$ twotailed), but significant difference for landscapes data set (Sahelian $M=0.019 \mathrm{sd}=0.00$ and Sudanian $M=0.018$, sd $=0.000$; $t(4)=5.682, p=0.005$ two-tailed). The magnitude of the RSI differences (means difference $=0.041,95 \% C I=-0.065$ to 0.146 ) was large (eta squared $=0.22$ ) and not significant for households data set, but greater and significant for landscapes data set (means difference $=0.002,95 \% C I=0.001$ to 0.003 ; eta squared $=0.89$ ).

\section{Similarity of FTS between Ecological Zones and Informants Data Sets}

To measure FTS similarity between the Sahelian and Sudanian zone, the Jaccard $(J S I)$ and Morisita-Horn $\left(C_{M H}\right)$ similarity indices were computed for households and landscapes data sets (Table 5). The $J S I$, which is based on the presence or absence of a species in a data set, indicates about $50 \%$ of similarity between FTS occurring in the Sahelian and the Sudanian zone, while the Morisita-Horn similarity index, which is based on the number of individual of a species recorded in a data set, indicates $86 \%$ of similarity between the two ecological zones for household surveys data. At the landscapes scale, $45 \%$ of similarity in FTS was detected between in the Sahelian and the Sudanian landscapes, according to Jaccard index, while the

Table 4.

Species richness.

\begin{tabular}{|c|c|c|c|c|}
\hline \multirow{2}{*}{ Species richness Indices } & \multicolumn{2}{|c|}{ Sahelian zone } & \multicolumn{2}{|c|}{ Sudanian zone } \\
\hline & Households & Landscape & Households & Landscape \\
\hline $\mathrm{Nb}$ of families & 11 & 12 & 14 & 16 \\
\hline $\mathrm{Nb}$ Genus & 15 & 17 & 20 & 23 \\
\hline $\mathrm{Nb}$ of Species (S) & 15 & 18 & 20 & 25 \\
\hline Reciprocal of Simpson index $(1 / D)$ & $6.726 \pm 0.952$ & $3.28 \pm 1.27$ & $6.145 \pm 0.576$ & $3.33 \pm 0.28$ \\
\hline $\begin{array}{l}\text { Mean species richness per } \\
\text { household and quadrat }\end{array}$ & $5 \pm 0.1$ & $2 \pm 1$ & $6 \pm 0.1$ & $3 \pm 1$ \\
\hline$R S I$ & $0.51 \pm 0.03$ & $0.02 \pm 00$ & $0.47 \pm 0.03$ & $0.02 \pm 00$ \\
\hline
\end{tabular}


D. N. E. THIOMBIANO ET AL.

Table 5.

Recorded FTS similarity between the Sahelian and Sudanian zones in households survey and landscapes inventory data sets in Burkina Faso.

\begin{tabular}{|c|c|c|c|c|c|}
\hline \multirow{2}{*}{ Ecological zones } & \multirow{2}{*}{ Origin of data sets } & \multicolumn{2}{|c|}{ Sahelian } & \multicolumn{2}{|c|}{ Sudanian } \\
\hline & & Household & Landscape & Household & Landscape \\
\hline \multicolumn{6}{|c|}{ Jaccard Similarity Index (JSI) } \\
\hline \multirow{2}{*}{ Sahelian } & Household & 1 & 0.55 & 0.50 & 0.43 \\
\hline & Landscape & & 1 & 0.29 & 0.45 \\
\hline \multirow{2}{*}{ Soudanian } & Household & & & 1 & 0.69 \\
\hline & Landscape & & & & 1 \\
\hline \multicolumn{6}{|c|}{ Morisita-Horn's Index of Similarity $\left(\mathrm{C}_{M H}\right)$} \\
\hline \multirow[b]{2}{*}{ Sahelian } & Household & 1 & 0.04 & 0.86 & 0.39 \\
\hline & Landscape & & 1 & 0.03 & 0.11 \\
\hline \multirow{2}{*}{ Soudanian } & Household & & & 1 & 0.74 \\
\hline & Landscape & & & & 1 \\
\hline
\end{tabular}

Morisita index indicated only $11 \%$ of similarity.

\section{Discussion}

This study focuses on FTS products that rural communities use and the potential of the landscape surrounding their villages, to supply these products. Data were collected at households and landscapes levels to measure whether the current demand of FTS products by some selected rural communities in Burkina Faso, matches the supplying capacity of the environment around the villages, and assess whether exploitation patterns are sustainable.

Our results indicate that rural communities are still using tree species as source of food in Burkina Faso. A total of 30 species were recorded in the two main ecological zones (Sahelian and Sudanian). With regard to what species are considered most important, the results of this study are supported by those obtained from previous investigations: 15 tree species whose products are used to prepare sauces and relishes were reported also by Mertz et al. (2001); furthermore, 17 tree species which are source of edible fruits and ingredients for sauces in the Sudanian zone, were reported also by Kristensen and Lykke (2003). Finally, 14 of the tree species recorded in this study as supplements to diets in the Sahelian region were reported also in a study by Ganaba et al. (2002). These results seem to indicate a general consensus on what tree species constitute a notable source of foods, with some specificity according to ecological regions.

Comparing frequencies of species occurrence in households and landscape data sets, considerable differences emerged between ecological zones. In accordance with our first hypothesis, some important FTS (according to household surveys) occurred at low density in the landscapes surrounding the villages studied, suggesting limited potentialities of these species to match the demands of FTS products. This situation was further supported by the low density of adults, except for Vitellaria paradoxa in the Sudanian zone. For example, Parkia biglobosa was recorded as important in $81 \%$ of the households surveyed in the Sahelian zone but was totally absent in the landscapes surrounding the study sites, both in the stage of seedlings and adults. This indicates that its products were brought in the area from sudanian areas and sold in the market place. Cunningham (2000) reported that the first typical response to resource scarcity is to increase the harvest range.

For most species, density of seedlings appeared greater than that of adults, in each ecological zone, suggesting that conditions are favorable to recruitment. Nevertheless, seedling densities seem low if compared to those reported by Bognounou et al. (2009) for a tree species giving non edible products, Pteleopsis suberosa (Combretaceae), with 21630 to 26120 individuals ha $^{-1}$ and those reported by Koadima (2008) for a FTS, Securidaca longepeduncula (Polygalaceae), with 7600 individuals $\mathrm{ha}^{-1}$ in landscapes surrounding villages of the Sudanian zone. Authors such as Boffa (2000) and Kozlowski (2002) pointed out the difficulties encountered by most tree species to regenerate and reach the adult stage, notably on annual cropland, due to various factors (failure of seeds to germinate, predators, pathogens, seedlings mortality and anthropogenic disturbances).

With regard to our second hypothesis about a predicted more diverse and richer wealth of FTS in the Sudanian zone, compared to the Sahelian zone, due to its higher rainfall, the comparison of the reciprocal of Simpson's diversity indices between the two zones did not exhibit any difference both for household surveys and landscape inventories datasets. The similarities in landscapes data could be explained by the fact that each zone has specific FTS but a large number of FTS are common. Similarities in households data can be explained by the fact that even if species such Parkia biglobosa and Detarium microcarpa were absent from the Sahelian landscape inventoried, these species appeared in the associated household surveys because traders import their products from the Sudanian zone. The trade of non-timber forest products across regions in Burkina Faso is considerable. Kernels of Sclerocarya birrea seeds and dry leaves of Adansonia digitata are largely exported from the Sahelian to the Sudanian zone (Lamien \& Traoré, 2002), while flour and seeds of Parkia biglobosa, and dry fruits of Detarium microcarpa, are exported from the Sudanian to the Sahelian zone (Lamien N., personal observations in 2008). Fresh fruits of Saba senegalensis and Lannea micro- 
carpa are also exported from production areas to main cities (Lamien et al., 2010). The comparison of the $1 / D$ index between households and landscapes data sets indicates greater values of $1 / D$ in households than landscapes data both in the Sahelian and Sudanian zones. The explanation could be linked to convergent customary habits, across households within the same ecological zone, of exploitation of a well-defined set of FTS, since ancestral times. Household surveys tend to produce homogeneous results for what concerns the range of most used species, with very limited differentiation. This is also supported by Kristensen and Lykke (2003) who found that all their informants had given the same answer to $28 \%$ of their questions. This suggests a consolidate transmission of traditional knowledge from a generation to the next, generating a cultural inertia in the use of natural resources found in the surrounding environment (Ladio \& Lozada, 2004; Cotton, 1996). This finding is further supported by other results in this study, such as the mean species richness per household and the RSI, whose values also are greater compared to those found from the landscapes data set; however, for these values, no significant difference between the Sahelian and Sudanian zone was found, suggesting convergent patterns between households of the two ecological zones. Nevertheless, differences in landscapes' RSI values between the two ecological zones, although very low, were significant, indicating a certain variability of species richness. The high Jaccard Similarity Index did not support this situation which seems more related to the species individuals as indicated by the low Morisita-Horn's similarity index.

\section{Conclusion}

In accordance with the first hypothesis formulated, this study reveals that the demand of FTS products by local communities, in some selected sites from two ecological zones of Burkina Faso, is exceeding the supply generated within in the areas surrounding the rural communities investigated. There is evidence that without adequate forest conservation and restoration initiatives, the areas surrounding villages will no longer meet the demand for FTS products. Lack of availability in a particular region is compensated by import of products from other areas. However, even those regions where climatic conditions are more favorable to support a more diverse range of FTS (e.g., Sudanian ecological zone), the most important FTS occur at low frequencies, both as seedlings and adults. The diversity and richness of FTS used by local communities are similar across the two regions, showing a tendency to utilize similar FTS. This seems linked to customary habits. On the contrary to the second hypothesis formulated in this paper, there is no evidence that the range of FTS in the Sudanian zone is more diverse and richer compared to that of the Sahelian zone of Burkina Faso, although densities of individual species are significantly different between the two zones. Our results call for conservation strategies to sustain the local communities' food tree species demand.

\section{Acknowledgements}

The authors are grateful to Africa-Brazil agricultural innovation marketplace and the National Institute for Agricultural and Food Scientific Research and Technology, (INIA, Spain), through a collaboration between Bioversity International, the Forest Research Center (CIFOR) of INIA, and several national partners from African countries, under the umbrella of SAFORGEN, the sub-Saharan African Forest Genetic Resources programme, which supported financially this study. Thanks to Dr Patrice Savadogo for his valuable comments on the manuscript.

\section{REFERENCES}

Bruce Bationo, A., Traore, Z., Kimetu, J., Bagayoko, M., Kihara, J., Bado, V., Lompo, M., Tabo, R., \& Koala, S. (2003). Cropping systems in the Sudano-sahelian zone: Implications on soil fertility management. http://www.syngentafoundation.org/db/1/432.pdf

Belem, B., Smith-Olsen, C., Theilade, I., Bellefontaine, R., Guinko, S. Lykke, A. M. et al. (2008). Identification des arbres hors forêt préférés des populations du Sanmatenga (Burkina Faso). Bois etForêts des Tropiques, 298, 53-60.

Boffa, J. M. (2000). West African agroforestry parklands: Keys to conservation and sustainable management. Unasylva, 51, 11-17.

Bognounou, F., Savadogo, P. Thiombiano, A., Tigabu, M., Boussim, I. J., Oden, P. C., \& Guinko, S. (2009). Impact of disturbance from roadworks on Pteleopsis suberosa regeneration in roadside environments in Burkina Faso, West Africa. Journal of Forestry Research, 20, 355-361. doi:10.1007/s11676-009-0060-9

Cotton, C. M. (1996). Ethnobotany: Principles and applications. Chichester, England: John Wiley and Sons.

Cunningham A. B. (2000). Applied ethnobotany: People, wild plant use and conservation $(300 \mathrm{p})$. London: Earth Scan.

FAO (2001). Global forest resource assessment. Rome: Food and Agriculture Organization of the United Nations.

Fontes, J., \& Guinko, S. (1995). Carte de végétation et de l'occupation d'un sol du Burkina Faso. Notice explicative. Ministère de la coopération française, Projet campus (8813101). Toulouse: Université Paul Sabatier.

Ganaba, S., Ouadba, J. M., \& Bognounou, O. (2002). Utilisation des ressources végétales spontanées comme complément alimentaire en région sahélienne du Burkina Faso. Annales de Botanique de l'Afrique de l'Ouest, 2, 101-112.

Gausset, Q., Yago-Ouattara, E. L., \& Belem, B. (2005). Gender and trees in Péni, South-Western Burkina Faso. Women's needs, strategies and challenges. Danish Journal of Geography, 105, 67-76. doi:10.1080/00167223.2005.10649527

Hasalkar, S., \& Jadhav, V. (2004). Role of Women in the use of Non-Timber. Forest produce: A Review. Journal Social Science, 8, 203-206.

INSD (2010). Résultats préliminaires du recensement général de la population et de l'habitat de 2009. Ouagadougou: Institut National des Statistiques et de la Démographie (INSD).

Koadima, M. (2008). Inventaire des espèces ligneuses utilitaires du parc $W$ et terroirs riverains du Burkina Faso et état des populations de trois espèces à grande valeur économiques (56 p). Ouagadougou: Université de Ouagadougou.

Kozlowski, T. T. (2002). Physiological ecology of natural regeneration of harvested and disturbed forest stands: Implication for forest management. Forest Ecology and Management, 158, 195-221. doi:10.1016/S0378-1127(00)00712-X

Krebs, J. C. (1999). Ecological methodology. New York: AddisonWesley Educational Publishers Inc.

Kristensen, M., \& Lykke, A. M. (2003). Informant-based valuation of use and conservation preferences of savanna trees in Burkina Faso. Economic Botany, 57, 203-217. doi:10.1663/0013-0001(2003)057[0203:IVOUAC]2.0.CO;2

Ladio, A. H., \& Lozada, M. (2004). Patterns of use and knowledge of wild edible plants in distinct ecological environments: A case study of a Mapuche community from north western Patagonia. Biodiversity and Conservation, 13, 1153-1173. doi:10.1023/B:BIOC. 0000018150.79156 .50

Lamien, N., \& Traoré, S. (2002). Commercialisation des produits non ligneux des arbres de la zone semi aride du Burkina Faso: Cas des feuilles sèches de Baobab (Adansonia digitata $\mathrm{L}$.). In Nouer des liens 


\section{N. E. THIOMBIANO ET AL.}

entre la recherche et le développement en agroforesterie dans les basses terres semi arides d'Afrique de l'ouest, $2^{\text {eme }}$ atelier régional sur les aspects socio-économiques de l'agroforesterie au sahel (pp. 1-9), Bamako: ICRAF.

Lamien, N., Lingani-Coulibaly, P., \& Traore-Gue, J. (2009). Importance of local fruits consumption in diet balance in Burkina Faso, West Africa. ActaHorticulturae, 806, 203-208.

Lamien, N., Traore, S., \& Kini, F. (2010). Potentialités productive, nutritive et économique de la liane goïne (Saba senegalensis A. DC. Pichon) dans le sahel burkinabè. Sahelian Studies and Research, 15, 115-124.

Langat, D., \& Cheboiwo, J. (2010). To conserve or not to conserve: A case study of forest valuation in Kenya. Journal of Tropical Forest Science, 22, 5-12.

Magurran, A. E. (2004). Measuring biological diversity (234 p). Oxford: Black-Well Science Ltd.

Mahamane, A., \& Saadou, M. (2008). Méthodes d'étude et d'analyse de la flore et de la végétation tropicales ( $82 \mathrm{p}$ ). Actes de l'atelier sur l'harmonisation des méthodes, tenu à Niamey du 4 au 9 août 2008.

Mertz, O., Lykke, A. M., \& Reenberg, A. (2001). Importance and seasonality of vegetable consumption and marketing in Burkina Faso. Economic Botany, 55, 276-289. doi:10.1007/BF02864565

Ouedraogo, I., Tigabu, M., Savadogo, P., Compaore, H., Oden, P. C., \& Ouadba, J. M. (2010). Land cover change and its relation with population dynamics in Burkina Faso, West Africa. Land Degradation and Development, 21, 1-10.

Pallant, J. (2010). SPSS survival manual: A step by step guide to data analysis using the SPSS program (4th ed.). England: McGraw-Hill Companies.
Paré, S. (2008). Land use dynamics, tree diversity and local perception of dry forest decline in Southern Burkina Faso, West Africa. Ph.D. Thesis, Uppsala: Swedish University of Agricultural Sciences.

Pimental, D., Nair, M. Mc., Buck, L., Pimental, M., \& Kamil, J. (1997). The value of forests to world food security. Human Ecology, 25, 91120. doi: $10.1023 / \mathrm{A}: 1021987920278$

Shackleton, S., \& Gumbo, D. (2010). Contribution of non-wood forest products to livelihoods and poverty alleviation. In E. Chidumayo, \& D. A. Gumbo (Eds.), The dry forests and woodlands of Africa: Managing for products and services (pp. 63-91). The Earthscan Forestry Library.

Shackleton, S., Charlie, 1., Shackleton, C., \& Shanley, P. (2011). Nontimber forest products in the global context (285 p). Heidelberg, Dordrecht, London, New York: Springer,

Soulama, S. (1990). Analyse économique des systèmes et structures alimentaires en zones à déficit céréaliers au Burkina Faso. In Stratégies et politiques alimentaires au Sahel. De la recherche à la prise de décision (pp. 175-198). UO/CILSS/Centre Sahel UL.

Thiombiano, D. N. E., Lamien, N., Dibong, D. S., Boussim, I. J., \& Belem, B. (2012). Le rôle des espèces ligneuses dans la gestion de la soudure alimentaire au Burkina Faso. Sécheresse, 23, 86-93.

Thomas, E., Vandebroek, I., Van Dammea, P., Goetghebeur, P., Douterlungne, D., Sanca, S., \& Arrazola, S. (2009). The relation between accessibility, diversity and indigenous valuation of vegetation in the Bolivian Andes. Journal of Arid Environments, 73, 854-861. doi:10.1016/j.jaridenv.2009.03.010

Zida, D. (2007). Impact of forest management regimes on ligneous regeneration in Sudanian Savanna of Burkina Faso. Doctoral Thesis, Uppsala: Swedish University of Agricultural Sciences. 